Civilian Radioactive Waste Management System

Management and Operating Contractor

\section{Repository Radiation Shielding Design Guide}

DI: BC0000000-01717-2500-00001

\section{Revision 00 DCN 1}

September 12, 1997

Prepared for:

U.S. Department of Energy

Yucca Mountain Site Characterization Office

P.O. Box 98608

Las Vegas, NV 89193-8608

Prepared by:

TRW Environmental Safety Systems, Inc.

1180 Town Center Drive

Las Vegas, NV. 89134

Under Contract Number

DE-AC01-91RW00134 


\section{Civilian Radioactive Waste Management System Management and Operating Contractor}

\section{Repository Radiation Shielding Design Guide}

September 12, 1997

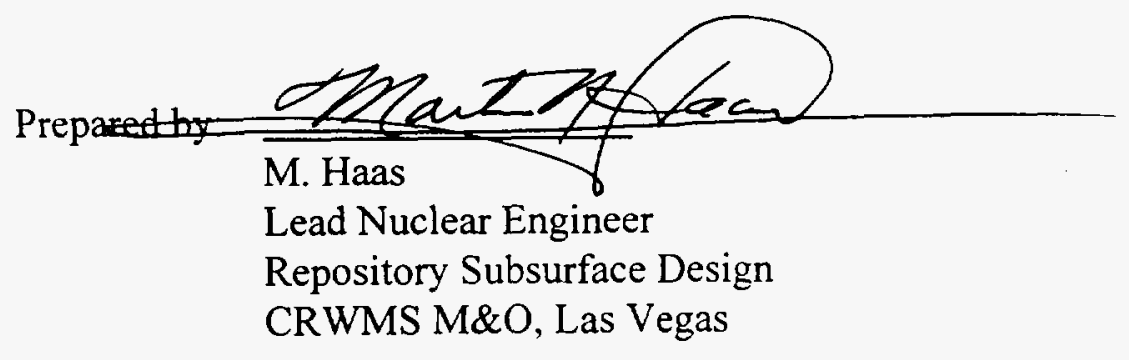

Prepared by: E: 217. Fertech

E. M. Fortsch

Lead Nuclear Engineer

Repository Surface Design

CRWMS M\&O, Las Vegas

Checked by:

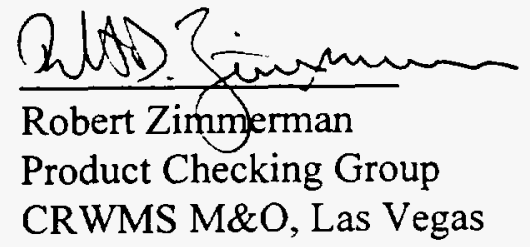

Approved by: Tleves onizen

Repository Surface Design Supervisor

Approved by:

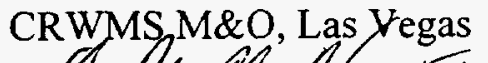

D.G. McKenzio

Repository Subsurface Design Supervisor

CRWMS M\&O, Las Vegas
Approved by: $\frac{k, k \text {. Sha tha }}{\text { Kalyan Bhattacharyya }}$
Department Manager Repository Design
CRWMS M\&O, Las Vegas 


\section{CONTENTS}

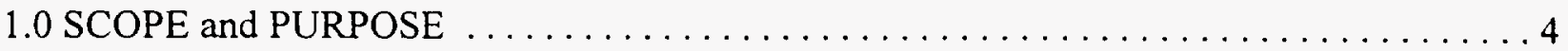

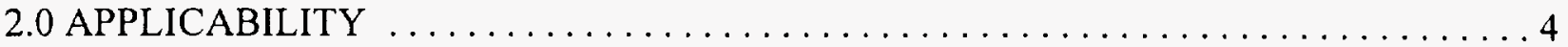

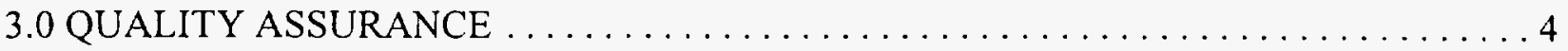

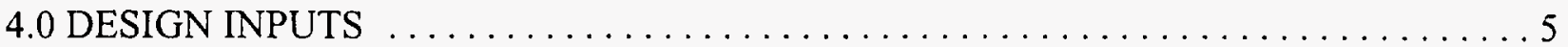

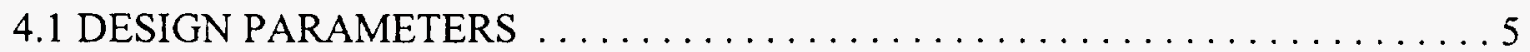

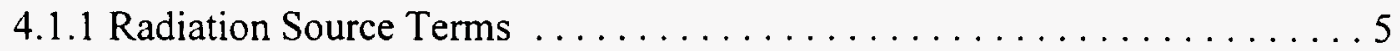

4.1.2 Time-dependent Neutron Source Data . . . . . . . . . . . . . . . . 7

4.1.3 Time-dependent Gamma Source Data . . . . . . . . . . . . . . 8

4.1.4 Co-60 Sources in Non-fuel Components . . . . . . . . . . . . . . 8

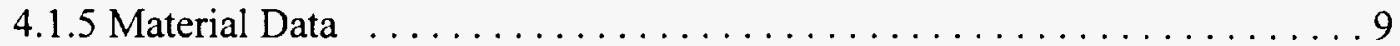

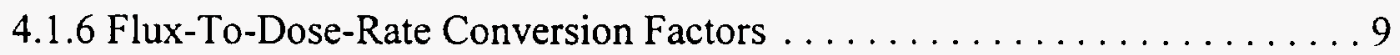

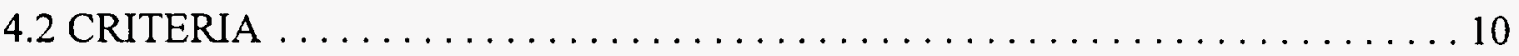

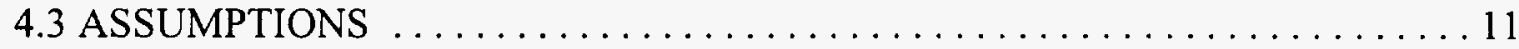

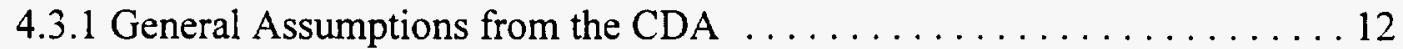

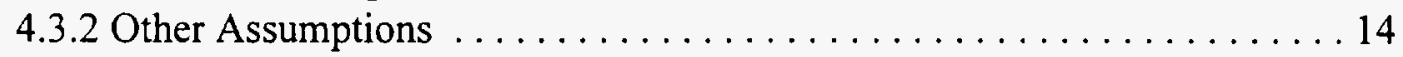

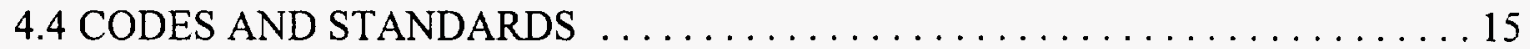

4.4.1 American National Standards Institute (ANSI) $\ldots \ldots \ldots \ldots \ldots \ldots \ldots 15$

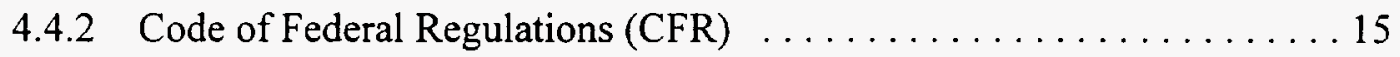

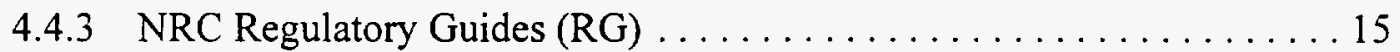

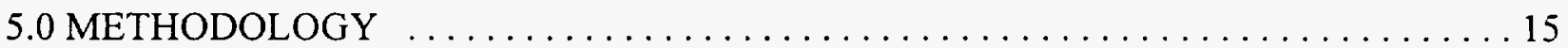

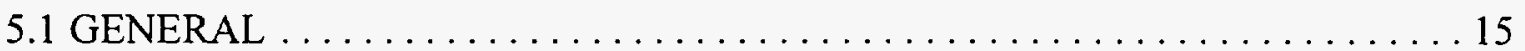

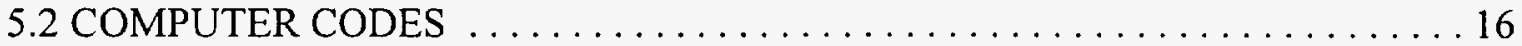

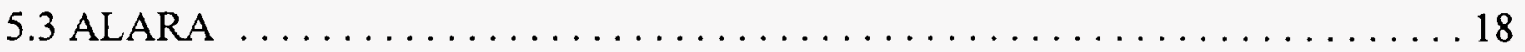

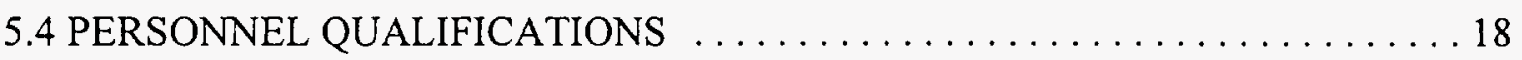

6.0 PERFORMANCE VERIFICATION $\ldots \ldots \ldots \ldots \ldots \ldots \ldots \ldots \ldots \ldots \ldots \ldots \ldots$

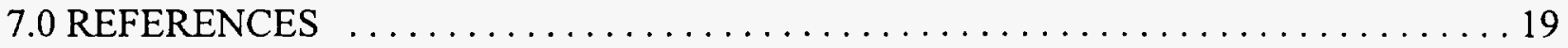

LIST OF ACRONYMS AND ABBREVIATIONS $\ldots \ldots \ldots \ldots \ldots \ldots \ldots \ldots \ldots \ldots$

ATTACHMENT I DESIGN BASIS FUEL PWR ACD DBF Gamma Source Data $\ldots \ldots \ldots 23$

ATTACHMENT II AVERAGE PWR SPENT FUEL SOURCE TERMS $\ldots \ldots \ldots \ldots \ldots$

ATTACHMENT III TIME-DEPENDENT GAMMA SOURCE DATA $\ldots \ldots \ldots \ldots \ldots \ldots 27$

ATTACHMENT IV MATERIAL DATA FOR SHIELDING ANALYSIS . . . . . . . 44 


\section{SCOPE and PURPOSE}

The scope of this document includes radiation safety considerations used in the design of facilities for the Yucca Mountain Site Characterization Project (YMP). The purpose of the Repository Radiation Shielding Design Guide is to document the approach used in the radiological design of the Mined Geologic Disposal System (MGDS) surface and subsurface facilities for the protection of workers, the public, and the environment. This document is intended to ensure that a common methodology is used by all groups that may be involved with Radiological Design. This document will also assist in ensuring the long term survivability of the information basis used for radiological safety design and will assist in satisfying the documentation requirements of the licensing body, the Nuclear Regulatory Commission (NRC).

This design guide provides referenceable information that is current and maintained under the YMP Quality Assurance (QA) Program. Furthermore, this approach is consistent with maintaining continuity in spite of a changing design environment. This approach also serves to ensure common inter-disciplinary interpretation and application of data.

\section{APPLICABILITY}

This Guide applies to the radiological design of the repository surface and subsurface facilities. The initial focus of the guide is on radiation shielding for workers and members of the public as well as for critical equipment which may be exposed to radiation. Later issues of this guide will include additional radiological design issues such as instrumentation, radiation effects on materials, and dosimetry. Radiation sources used in this Guide are based on commercial spent nuclear fuel (SNF), including pressurized water reactor (PWR) and boiling water reactor (BWR), and on Defense High Level Waste (DHLW). Not included at this time are the various forms of Department of Energy Spent Nuclear Fuel (DOE/SNF) that are being considered for inclusion in the repository.

\section{QUALITY ASSURANCE}

This document serves as a guide for the performance of calculations affecting radiological aspects of health and safety. Although, the classification of permanent items described in QAP-2-3 Classification of Permanent Items has not been performed for the Structures, Systems and Components (SSCs) applicable to this Radiation Safety Design Guide, an activity evaluation has been performed in accordance with procedure QAP-2-0 and has determined that the activities addressed in this Guide are subject to the requirements of the Quality Assurance Requirements and Description (QARD)(Reference 7.1), because this Guide affects items on the Q-List (Reference 7.25). However, since this Guide will not be used for procurement, fabrication, or construction, any assumptions identified do not need to be marked TBV or tracked in accordance with appropriate QA procedures.

This classification of SSC's described in QAP-2-3 will be performed in the future apart from this Design Guide. 


\section{DESIGN INPUTS}

A number of the design inputs used in Radiological Design are documented in the following sections. These are representative of the type and pedigree of information used and are not exhaustive. Additional resources may be needed to address a particular problem.

To the extent practical, project-maintained documents are used for design inputs to shielding calculations. Included are such documents as the Controlled Design Assumptions Document (CDA), Reference 7.3, the Repository Design Requirements Document (RDRD), Reference 7.4, and the Engineered Barrier Design Requirements Documents (EBDRD), Reference 7.5. Alternatively, use is made of data sources from referable sources with demonstrated acceptance from a NRC regulatory perspective whenever such data are required that is not otherwise available from project-maintained documents.

\subsection{DESIGN PARAMETERS}

\subsubsection{Radiation Source Terms}

The radiation source terms used in radiological design are, to the extent possible, based on the Characteristic Data Base (CDB), Reference 7.6 as used in the CDA Document, Reference 7.3, assumption EBDRD 3.2.3.4.C.4. The CDB is currently available as a computer code information database. Output from the CDB includes detailed burnup data in the form of isotopic composition of spent nuclear fuel. Additionally, the CDB calculates both the gamma and neutron source components of the overall radiation field which emanates from either SNF or DHLW. The strength and spectra of such radiation fields are dependent upon several parameters including initial enrichment, initial fuel loading, irradiation burnup history, decay time, and the specifics of fuel type. In the case of SNF, the fuel type may be either PWR or BWR based designs. The CDB, which is based on a number of calculations using the ORIGEN2 code, Reference 7.7, provides a ready reference for selected parameter values. A variant of this code has also been incorporated into the SCALE 4.3(see Ref. 7.8) system of computer codes.

Depending upon the application and goals, different parameter values may be selected for the radiation source terms. Examples of the possible variety are noted as follows:

The Design Basis Fuel (DBF) as defined in this report is for shielding calculations and has been derived from the Advanced Conceptual Design (ACD) Report(Ref. 7.24). This is not necessarily the same as the Design Basis Fuel as used in other analysis for thermal or criticality calculations.

\section{Maximum Possible Radiation Source for Shielding}

The maximum radiation source from irradiated nuclear fuel assemblies is typically defined by the following factors:

- maximum fuel content, or Metric Ton Initial Heavy Metal (MTIHM)
- maximum burnup
- minimum enrichment
minimum decay

Based on current fuel designs, some PWR fuel assemblies may undergo burnup histories as high as 70,000 MWd/MTIHM. Similarly, for BWR fuel, the burnup histories may be 
A survey of the different types of fuel assemblies in the CDB, Reference 7.6, indicates that irradiations of fuel assemblies containing a total of 1,661 MTIHM of fuel from the South Texas Project (STP) may contain a combination of initial fuel loading, burnup, and enrichment which may result in the maximum radiation source. The radiation from this source may be greater than the Advanced Conceptual Design (ACD) Design Basis Fuels (DBF) Radiation Source (Ref. 7.24) [discussed in the following paragraphs] by $17 \%$ based on initial MTIHM loading alone as indicated in the analysis of Reference 7.6.

These fuel assemblies represent a very minor fraction of the overall total of $70,000 \mathrm{MTU}$ of SNF expected to be emplaced in the repository. No other fuel assemblies were found to potentially exceed the ACD DBF Radiation Source. Furthermore, it is unknown at this time if the STP assemblies will ultimately be irradiated to their maximum burnup limit. Consequently, the higher STP source term has not been selected for design application until such time as it has been determined whether this is indeed the limiting source term or whether such SNF cannot be accommodated by special processing; e.g., either by blending with lower burnup fuel or by special handling at the repository.

\section{Design Basis Fuel Radiation Source}

The ACD DBF have been described in Reference 7.24 to bound the majority of SNF expected to be received at the MGDS from a radiological and thermal standpoint. This bounding is based on SNF being received according to the "oldest-fuel-first" scenario. Moreover, as a conservative measure, it is assumed that such SNF is received with the minimum decay of 10 years as stipulated in Reference 7.9 .

Note: 5 year old fuel may be received at the repository as required by contract. Higher radiation doses resulting from this fuel can be handled by operational controls. Other sources will be developed as required.

These are further described in Table $4-1$ as follows:

\begin{tabular}{|l|l|l|l|l|l|}
\hline \multicolumn{5}{|c|}{ Table 4-1: Design Basis Fuel Radiation Source } \\
\hline $\begin{array}{l}\text { Fuel } \\
\text { Type }\end{array}$ & $\begin{array}{l}\text { SNF } \\
\text { Population } \\
\text { Bounded }\end{array}$ & $\begin{array}{l}\text { Burnup } \\
\text { (MWd/MTIHM) }\end{array}$ & $\begin{array}{l}\text { Initial } \\
\text { Enrichment } \\
\text { (weight \%) }\end{array}$ & $\begin{array}{l}\text { Age } \\
\text { (years) }\end{array}$ & $\begin{array}{l}\text { Initial } \\
\text { Fuel } \\
\text { Loading } \\
\text { (MTHHM) }\end{array}$ \\
\hline PWR & $97.85 \%$ & 48,086 & 4.2 & 10 & 0.464 \\
\hline BWR & $100 \%$ & 49,000 & 3.74 & 10 & 0.196 \\
\hline
\end{tabular}

It is assumed that derating or blending various fuel assemblies may be required to accommodate fuel which exceeds the ACD DBF in the previous table. Therefore use of the ACD DBF will provide a conservative radiation source term for shielding analysis.

Additional information regarding radiation source terms derived from the specifications 
for the PWR SNF is described in Attachment I. Included are detailed gamma and neutron source strengths and spectra for use in shielding design work.

\section{Average Radiation Source}

The average SNF radiation source is typically used in ALARA assessments to be as representative of the average of radiation conditions to be encountered. As noted in Reference 7.3, Key assumption 004, the average SNF may be described in Table 4.2 as follows:

\begin{tabular}{|l|l|l|l|}
\hline \multicolumn{4}{|c|}{ Table 4-2: Average Radiation Source } \\
\hline $\begin{array}{l}\text { Fuel } \\
\text { Type }\end{array}$ & $\begin{array}{l}\text { Burnup } \\
\text { (MWd/MTIHM) }\end{array}$ & $\begin{array}{l}\text { Initial } \\
\text { Enrichment } \\
\text { (weight \%) }\end{array}$ & $\begin{array}{l}\text { Age } \\
\text { (years) }\end{array}$ \\
\hline PWR & 39,750 & 3.72 & 26.4 \\
\hline BWR & 31,490 & 3.00 & 26.5 \\
\hline
\end{tabular}

The data of Table 4-2 is based on the oldest-fuel-first scenario with no fuel younger than 10 years old being accepted at the repository. A further description of the gamma and neutron source terms for the Average radiation source term for the PWR SNF is contained in Attachment II.

\subsubsection{Time-Dependent Neutron Source Data}

The following time-dependent neutron source data for the PWR SNF are used to determine the neutron radiation field from the waste packages as a function of time for a maintainable preclosure service life of at least 150 years (Ref. 7.3, p. 4-11) after initiation of waste emplacement. The initial emplacement time corresponds to a decay time of 10 years as defined for ACD DBF. The end of the service life, therefore corresponds to a decay time of 160 years. The data are for $4.2 \%$ initial enrichment and 48,086 MWd/MTIHM burnup corresponding to the ACD DBF.

\begin{tabular}{|l|l|l|}
\hline \multicolumn{3}{|c|}{ Table 4-1.2: Time-dependent Neutron Source Data } \\
\hline $\begin{array}{l}\text { Decay Time } \\
(\mathrm{Yr})\end{array}$ & $\begin{array}{l}\text { Time After Emplacement } \\
(\mathrm{Yr})\end{array}$ & $\begin{array}{l}\text { Neutron Source Strength } \\
(\mathrm{n} / \mathrm{s}-\mathrm{MTHHM})^{\mathrm{a}}\end{array}$ \\
\hline 10 & 0 & $6.74 \mathrm{e}+08$ \\
\hline 15 & 5 & $5.60 \mathrm{e}+08$ \\
\hline 20 & 10 & $4.67 \mathrm{e}+08$ \\
\hline 30 & 20 & $3.25 \mathrm{e}+08$ \\
\hline 40 & 30 & $2.29 \mathrm{e}+08$ \\
\hline 50 & 40 & $1.62 \mathrm{e}+08$ \\
\hline 60 & 50 & $1.18 \mathrm{e}+08$ \\
\hline 70 & 60 & $8.78 \mathrm{e}+07$ \\
\hline 80 & 70 & $6.66 \mathrm{e}+07$ \\
\hline 90 & 80 & $5.18 \mathrm{e}+07$ \\
\hline 100 & 90 & $3.97 \mathrm{e}+07$ \\
\hline
\end{tabular}




\begin{tabular}{|l|l|l|}
\hline \multicolumn{2}{|c|}{ Table 4-1.2: Time-dependent Neutron Source Data } \\
\hline $\begin{array}{l}\text { Decay Time } \\
(\mathrm{Yr})\end{array}$ & $\begin{array}{l}\text { Time After Emplacement } \\
(\mathrm{Yr})\end{array}$ & $\begin{array}{l}\text { Neutron Source Strength } \\
(\mathrm{n} / \mathrm{s}-\mathrm{MTTHM})^{\mathbf{1}}\end{array}$ \\
\hline 110 & 100 & $3.28 \mathrm{e}+07$ \\
\hline 120 & 110 & $2.80 \mathrm{e}+07$ \\
\hline 130 & 120 & $2.46 \mathrm{e}+07$ \\
\hline 140 & 130 & $2.22 \mathrm{e}+07$ \\
\hline 150 & 140 & $2.05 \mathrm{e}+07$ \\
\hline 160 & 150 & $1.93 \mathrm{e}+07$ \\
\hline
\end{tabular}

"part of computer output from Ref. 7.6

These parameters are used for time-dependent neutron radiation conditions.

\subsubsection{Time-dependent Gamma Source Data}

Attachment III provides the time-dependent gamma source data used to determine the active fuel gamma radiation field from the waste packages as a function of time for the 150-year maintainable preclosure service life (Ref. 7.3, p. 4-11) after initial emplacement. The initial emplacement time corresponds to a decay time of 10 years as defined for ACD DBF. The end of the maintainable preclosure service life corresponds to a decay time of 160 years. The data are for $4.2 \%$ initial enrichment and $48,086 \mathrm{MWd} / \mathrm{MTIHM}$ burnup. The decay times include those as given in Section 4.1.2 for the time-dependent neutron source data. All the data are reproduced from the computer output of the CDB (Ref. 7.6).

\subsubsection{Co-60 Sources in Non-fuel Components}

The upper and lower end fittings of those fuel assemblies containing stainless steel may contain Co-60 sources, which are due to neutron activation of non-fuel components during reactor operation. These sources may contribute significantly to radiation fields, however, the individual analyst should evaluate each specific case to determine all applicable sources. The following data, obtained from Reference 7.6 for PWR SNF are used to derive the Co-60 source terms for ACD DBF and average SNF:

$\begin{array}{lc}\frac{\text { Region }}{\text { Upper End Fittings }} & \text { Co-60 Activity (Ci/assembly) } \\ \text { Gas Plenum } & 111.5 \\ \text { Lower End Fittings } & 57.64 \\ & 151\end{array}$

"From Ref. 7.6, computer output for $4.73 \%$ enrichment, $60000 \mathrm{MWd} / \mathrm{MTIHM}$ burnup and 10 years decay.

These parameters are used to obtain the Co-60 generated source terms.

An additional potential source of Co-60 not considered here is from deposits of corrosion and wear products which may reside on surfaces of fuel assemblies. Such deposits generally contain much lower amounts of $\mathrm{Co}-60$ than that contained in end fittings. They are however a potential source of loose radioactive material which should be considered on a case-by-case basis in analysis as in Reference 7.23 . 


\subsubsection{Material Data}

The material data required in radiological design analysis include the density and elemental isotopic composition for each material. Data used in shielding design are based on standard material handbooks and published YMP documents, and are consistent with those used throughout the project (e.g., Waste Package Development Department). The materials considered include those for the waste form, waste package, WP transporter, emplacement drift, host tuff medium, etc. Attachment IV lists the pertinent material data used in radiological design analysis.

\subsubsection{Flux-To-Dose-Rate Conversion Factors}

The flux-to-dose-rate conversion factors are used to convert the calculated neutron and gamma fluxes to dose rates. These factors are based on the ANSVANS-6.1.1-1977 Standard ${ }^{1}$ (Reference. 7.10).

\begin{tabular}{|r|r|r|r|}
\hline \multicolumn{4}{|c|}{ Table 4-1.6a: Neutron Flux-To-Dose-Rate Conversion Factors } \\
(Ref. 7.10, p. 4) \\
\hline $\begin{array}{c}\text { Neutron } \\
\text { Energy (MeV) }\end{array}$ & $\begin{array}{c}\text { Conversion } \\
\text { Factors } \\
(\mathrm{mrem} / \mathrm{hr}) / \\
\left(\mathrm{n} / \mathrm{cm}^{2}-\mathrm{sec}\right)\end{array}$ & $\begin{array}{c}\text { Neutron } \\
\text { Energy }(\mathrm{MeV})\end{array}$ & $\begin{array}{c}\text { Conversion } \\
\text { Factors } \\
(\mathrm{mrem} / \mathrm{hr}) / \\
\left(\mathrm{n} / \mathrm{cm}^{2}-\mathrm{sec}\right)\end{array}$ \\
\hline $2.50 \mathrm{e}-08$ & $3.67 \mathrm{e}-03$ & $5.00 \mathrm{e}-01$ & $7.14 \mathrm{e}-02$ \\
\hline $1.00 \mathrm{e}-07$ & $3.67 \mathrm{e}-03$ & $1.00 \mathrm{e}+00$ & $1.18 \mathrm{e}-01$ \\
\hline $1.00 \mathrm{e}-06$ & $4.46 \mathrm{e}-03$ & $2.50 \mathrm{e}+00$ & $1.25 \mathrm{e}-01$ \\
\hline $1.00 \mathrm{e}-05$ & $4.54 \mathrm{e}-03$ & $5.00 \mathrm{e}+00$ & $1.56 \mathrm{e}-01$ \\
\hline $1.00 \mathrm{e}-04$ & $4.18 \mathrm{e}-03$ & $7.00 \mathrm{e}+00$ & $1.47 \mathrm{e}-0.1$ \\
\hline $1.00 \mathrm{e}-03$ & $3.76 \mathrm{e}-03$ & $1.00 \mathrm{e}+01$ & $1.47 \mathrm{e}-01$ \\
\hline $1.00 \mathrm{e}-02$ & $3.57 \mathrm{e}-03$ & $1.40 \mathrm{e}+01$ & $2.08 \mathrm{e}-01$ \\
\hline $1.00 \mathrm{e}-01$ & $2.08 \mathrm{e}-02$ & $2.00 \mathrm{e}+01$ & $2.27 \mathrm{e}-01$ \\
\hline
\end{tabular}

The revised version of ANSU/ANS-6.1.1 was published in 1991. The NRC has decided to defer acceptance until there is greater scientific consensus on the most appropriate values. Until such time as the 1991 standard is accepted, the ANSIANS-6.1.1-1977 Standard will be used.

\begin{tabular}{|r|r|}
\hline \multicolumn{2}{|c|}{$\begin{array}{l}\text { Table 4-1.6b: Gamma-Ray-Flux-To-Dose-Rate } \\
\text { Conversion Factors (Ref. 7.10, p. 5) }\end{array}$} \\
\hline $\begin{array}{l}\text { Photon Energy } \\
(\mathrm{MeV})\end{array}$ & $\begin{array}{l}\text { Conversion Factors } \\
(\mathrm{rem} / \mathrm{hr}) /\left(\text { photons } / \mathrm{cm}^{2}-\mathrm{s}\right)\end{array}$ \\
\hline $1.00 \mathrm{e}-02$ & $3.96 \mathrm{e}-06$ \\
\hline $3.00 \mathrm{e}-02$ & $5.82 \mathrm{e}-07$ \\
\hline $5.00 \mathrm{e}-02$ & $2.90 \mathrm{e}-07$ \\
\hline $7.00 \mathrm{e}-02$ & $2.58 \mathrm{e}-07$ \\
\hline
\end{tabular}




\begin{tabular}{|r|r|}
\hline \multicolumn{2}{|c|}{$\begin{array}{c}\text { Table 4-1.6b: Gamma-Ray-Flux-To-Dose-Rate } \\
\text { Conversion Factors (Ref. 7.10, p. 5) }\end{array}$} \\
\hline $\begin{array}{r}\text { Photon Energy } \\
(\mathrm{MeV})\end{array}$ & $\begin{array}{l}\text { Conversion Factors } \\
\left.\text { (rem/hr)/(photons/cm }{ }^{2}-\mathrm{s}\right)\end{array}$ \\
\hline $1.00 \mathrm{e}-01$ & $2.83 \mathrm{e}-07$ \\
\hline $1.50 \mathrm{e}-01$ & $3.79 \mathrm{e}-07$ \\
\hline $2.00 \mathrm{e}-01$ & $5.01 \mathrm{e}-07$ \\
\hline $2.50 \mathrm{e}-01$ & $6.31 \mathrm{e}-07$ \\
\hline $3.00 \mathrm{e}-01$ & $7.59 \mathrm{e}-07$ \\
\hline $3.50 \mathrm{e}-01$ & $8.78 \mathrm{e}-07$ \\
\hline $4.00 \mathrm{e}-01$ & $9.85 \mathrm{e}-07$ \\
\hline $4.50 \mathrm{e}-01$ & $1.08 \mathrm{e}-06$ \\
\hline $5.00 \mathrm{e}-01$ & $1.17 \mathrm{e}-06$ \\
\hline $5.50 \mathrm{e}-01$ & $1.27 \mathrm{e}-06$ \\
\hline $6.00 \mathrm{e}-01$ & $1.36 \mathrm{e}-06$ \\
\hline $6.50 \mathrm{e}-01$ & $1.44 \mathrm{e}-06$ \\
\hline $7.00 \mathrm{e}-01$ & $1.52 \mathrm{e}-06$ \\
\hline $8.00 \mathrm{e}-01$ & $1.68 \mathrm{e}-06$ \\
\hline $1.00 \mathrm{e}+00$ & $1.98 \mathrm{e}-06$ \\
\hline $1.40 \mathrm{e}+00$ & $2.51 \mathrm{e}-06$ \\
\hline $1.80 \mathrm{e}+00$ & $2.99 \mathrm{e}-06$ \\
\hline $2.20 \mathrm{e}+00$ & $3.42 \mathrm{e}-06$ \\
\hline $2.60 \mathrm{e}+00$ & $3.82 \mathrm{e}-06$ \\
\hline $2.80 \mathrm{e}+00$ & $4.01 \mathrm{e}-06$ \\
\hline $3.25 \mathrm{e}+00$ & $4.41 \mathrm{e}-06$ \\
\hline $3.75 \mathrm{e}+00$ & $4.83 \mathrm{e}-06$ \\
\hline $4.25 \mathrm{e}+00$ & $5.23 \mathrm{e}-06$ \\
\hline $4.75 \mathrm{e}+00$ & $5.60 \mathrm{e}-06$ \\
\hline $5.00 \mathrm{e}+00$ & $5.80 \mathrm{e}-06$ \\
\hline $5.25 \mathrm{e}+00$ & $6.01 \mathrm{e}-06$ \\
\hline $5.75 \mathrm{e}+00$ & $6.37 \mathrm{e}-06$ \\
\hline $6.25 \mathrm{e}+00$ & $6.74 \mathrm{e}-06$ \\
\hline $6.75 \mathrm{e}+00$ & $7.11 \mathrm{e}-06$ \\
\hline $7.50 \mathrm{e}+00$ & $7.66 \mathrm{e}-06$ \\
\hline $9.00 \mathrm{e}+00$ & $8.77 \mathrm{e}-06$ \\
\hline $1.10 \mathrm{e}+01$ & $1.03 \mathrm{e}-05$ \\
\hline $1.30 \mathrm{e}+01$ & $1.18 \mathrm{e}-05$ \\
\hline $1.50 \mathrm{e}+01$ & $1.33 \mathrm{e}-05$ \\
\hline & \\
\hline & \\
\hline & \\
\hline & \\
\hline & \\
\hline & \\
\hline &
\end{tabular}

\subsection{CRITERIA}

The following design criteria were developed in response to the requirements found in the RDRD (Ref. 7.4) that specifically apply to this Design Guide. RDRD requirements are cited for each criteria statement.

4.2.1 Occupational radiation exposures shall be maintained as low as reasonably achievable (ALARA), and within the exposure dose limits specified in 10CFR20.1201. (RDRD 3.2.2.1.A, RDRD 3.2.2.1.B, and RDRD 3.2.2.1.C) 
For shielding design analysis, the controlling limit is the total effective dose equivalent (TEDE) of $5 \mathrm{rem}$ per year. To meet the $5 \mathrm{rem} / \mathrm{yr}$ limit, the shielding shall be designed not to exceed a dose rate of $2.5 \mathrm{mrem} / \mathrm{hr}$ in normally occupied areas (based on a $40 \mathrm{hr} / \mathrm{wk} 50 \mathrm{wk} / \mathrm{yr}$ occupational access). Higher dose rate limits may be allowed in intermittently occupied areas depending upon occupancy time, and frequency of exposure, provided that individual annual exposures are within the 5 rem/yr limit.

4.2.2 For ALARA considerations, radiation shielding shall be designed with the goal of limiting the TEDE to less than 1 rem per year to workers, which is one-fifth of the 10CFR20.1201 annual occupational exposure limit. (RDRD 3.2.4.5.1.A, RDRD 3.2.4.5.1.B, RDRD 3.2.4.5.1.D)

The ALARA limit of $1 \mathrm{rem} / \mathrm{yr}$ corresponds to $0.5 \mathrm{mrem} / \mathrm{hr}$ for normally occupied areas based on a $40 \mathrm{hr} / \mathrm{wk}$ occupational access. Other areas requiring intermittent access may be designed using higher dose rate limits based on occupancy time, and frequency of exposure, provided that the ALARA goal of $1 \mathrm{rem} / \mathrm{yr}$ per individual is met.

This criteria statement is used for dose assessment.

4.2.3 The concrete shadow shields provided near the entrances (east and west entrances) of each emplacement drift for radiation protection purposes shall comply with ANSI/ANS 6.4 and ACI 349. For other shields, ACI 318 is appropiate and provides adequate strength for design earthquake loads (DE)(RDRD 3.2.4.5.1.C)

This criteria statement is used for specification of concrete density and material composition for radiation shielding analysis.

4.2.4 Suitable shielding shall be provided to maintain radiation doses in restricted areas of the Geologic Repository Operations Areas (GROA) within the limits specified in 10CFR20. (RDRD 3.7.7.A)

This criteria statement applies to the waste package transporter shielding, in-drift concrete shadow shields, and drift entrance doors.

4.2.5 The Geologic Repository Operations Area (GROA) shall, to the extent practicable, be designed and constructed to use procedures and engineering controls based on sound radiation protection principles to achieve occupational doses and doses to members of the public that are ALARA. ALARA principles shall be based on the applicable sections of the NRC Regulatory Guides 8.8 and 8.10. (RDRD 3.2.2.1.A)

4.2.6 Shielding and other radiation protection measures shall be provided for areas requiring intermittent access, such as for preventive maintenance, component changes, adjustment of systems and equipment, and so forth, with the goal of limiting dose rates based on occupancy, time, and frequency of exposure to one rem per year. (RDRD 3.2.4.5.1.B)

\subsection{ASSUMPTIONS}




\subsubsection{General Assumptions from the CDA}

The following section contains relevant excerpts from the Controlled Design Assumptions (CDA) Document (Ref. 7.3) that apply to this Design Guide. Rationale for each of these assumptions is provided in Ref. 7.3.

4.3.1.1 The average commercial spent fuel characteristics upon receipt at the repository are: 26.4 years old with 39,750 MWD/MTU burnup and 3.72 wt.\% enrichment (PWR) and 26.5 years old with 31,490 MWD/MTU burnup and $3.00 \mathrm{wt} . \%$ enrichment (BWR). (CDA Key Assumption 004)

For this Guide, the design basis fuel is PWR Fuel and the decay time is changed to 26 years. Rationale for this deviation: The CDB contains the source data only for integer year values. Use of 26 years produces a slightly higher radiation source strength for shielding analysis. This assumption is used to specify the source data for average SNF.

4.3.1.2 Waste packages will be emplaced in-drift in a horizontal mode. (CDA Key Assumption 011)

4.3.1.3 Waste packages will be placed center in-drift, on pedestals, using gantry emplacement. (CDA Key Assumption 066)

For shielding models, the shielding effect of pedestals and gantry equipment is ignored for conservatism. This assumption is used for in-drift waste package modeling.

4.3.1.4 No human entry is planned in emplacement drifts while WPs are present. The waste emplacement/retrieval equipment may use robotics and/or remote control features to perform operations and monitoring within the emplacement drifts to avoid personnel radiation exposures. Under off-normal conditions, human entry will be considered if protection to workers can be provided such as shielding. (CDA Key Assumption 013)

This assumption is used to evaluate radiation hazards to repository personnel and the need for personnel shielding for off-normal conditions.

4.3.1.5 WP containment barriers will provide sufficient shielding for protection of WP materials from radiation enhanced corrosion. Individual WPs will not provide any additional shielding for personnel protection. Additional shielding for personnel protection will be provided on the subsurface transporter and in subsurface facilities. (CDA Key Assumption 031)

This assumption is used to provide shielding for personnel protection.

4.3.1.6 The following diameters (meters) are assumed for underground openings: (CDA Key Assumption 070) 


$\begin{array}{ll}\text { Ramps } & 7.62 \\ \text { Access/Service Main } & 7.62 \\ \text { Emplacement Drift } & \text { TBD }\end{array}$

This assumption is used to account for drift wall scattering effects in the waste package transporter shielding analysis.

4.3.1.7 Inventories of radionuclides will be based on the Characteristics Data Base. (CDA EBDRD 3.2.3.4.C.4)

This assumption is used to obtain all radiation source data for use in shielding analyses.

4.3.1.8 Engineered Barrier Segment (EBS) structures, systems, and components shall be designed for a maintainable preclosure service life of at least 150 years following first emplacement of waste. (CDA EBDRD 3.2.5.4)

This assumption is used for determination of time-dependent doses.

4.3.1.9 The external dimensions of the waste package for a) commercial SNF that is repackaged and for b) uncanistered commercial SNF shall not exceed: (CDA EBDRD 3.7.1.J.1)

Outer Diameter: $\quad 1.85 \mathrm{~m}$

Outer length: $\quad 5.85 \mathrm{~m}$

These dimensions are used to establish the inside dimensions of the waste package transporter.

4.3.1.10 A $35 \mathrm{~m}$ thermal standoff distance is used to limit the surface rock temperature of the adjacent main drift. The thermal standoff is defined as the perpendicular distance from the center of the closest emplaced waste package to the nearest edge of the main drift. (CDA DCSS 033)

A $13 \mathrm{~m}$ radiological standoff distance is used for determining the limiting configuration in the evaluation of radiological dose rates in the adjacent main drift. The radiological standoff is defined as the distance from the center of the closest emplaced waste package to the door of the emplacement drift. This distance is equal to the sum of the distances from the doors to the edge of the waste package $(10 \mathrm{~m})$ plus half the length of the waste package (approximately $3 \mathrm{~m})$.(CDA DCSS 033)

4.3.1.11 Doors are required at entrances to emplacement drifts. (CDA DCSS 036)

This assumption is used for the drift entrance door shielding analysis.

4.3.1.12 The Surface Facilities that house radioactive materials or in which work is performed on radioactive materials will be designed to control occupational 
exposures to as low as reasonably achievable (ALARA) and less than 500 millirem per year. (CDA DCS 003)

4.3.1.13 As low as reasonably achievable (ALARA) studies will be conducted as needed to establish the allowable dose rates upon which various radiological safety calculations will be based. (CDA DCS 004)

\subsubsection{Other Assumptions}

4.3.2.1 The dose rate limit for shielding analysis of the waste package transporter is assumed to be $50 \mathrm{mrem} / \mathrm{hr}$ on the general accessible surfaces of the transporter, which includes the sidewall and end surfaces. The dose rate limit for the bottom surface of the transporter where access is normally not required is assumed to be $100 \mathrm{mrem} / \mathrm{hr}$. Rationale: Personnel access requirements in the vicinity of the transporter when loaded with a waste package have not been established. Typically, on-site transfer casks at nuclear power plants or other nuclear facilities were designed to a surface dose rate of 50 to $200 \mathrm{mrem} / \mathrm{hr}$. For preliminary design of the waste package transporter, it is prudent to use the lower end of the 50 to $200 \mathrm{mrem} / \mathrm{hr}$ range, namely, $50 \mathrm{mrem} / \mathrm{hr}$ for the general accessible surfaces. No access is required to the bottom surface of the transporter for normal conditions. A higher dose rate limit is acceptable on this surface. The limit of $100 \mathrm{mrem} / \mathrm{hr}$ is assumed to limit the scattering contributions off the floor, and avoid being classified as a "high radiation area". This assumption is used for the waste package transporter shielding design and will be the subject of an ALARA study as will any other radiological design.

4.3.2.2 For radiation analysis of multiple waste packages in the same emplacement drift, any intervening waste package is assumed to be an opaque object for direct radiation (i.e., direct contribution without scattering off the drift wall), but transparent for scattered or albedo radiation off the drift wall. Rationale: This assumption is conservative to estimate the radiation dose contributions from multiple waste packages. The closed waste package is the principal contributor to the radiation fields in the main drift and turnout areas. This waste package will block virtually all direct radiation from other waste packages in the same drift, leaving the contributions arising from scattering off the drift wall only. This assumption ignores the presence of the intervening waste packages for scattered radiation off the drift wall, which conservatively over-estimates the scattering contributions. This assumption is used to estimate the radiation fields for multiple waste packages.

4.3.2.3 The waste package loading dock at the drift entrance door is omitted in the emplacement drift model. Rationale: The loading dock is a concrete structure which would reduce contributions of radiation scattering off the bottom portion of the drift wall to the radiation fields in the main drift and turnout 
areas. Ignoring this dock in the model would result in a higher dose rate, which is conservative for personnel protection. .

\subsection{CODES AND STANDARDS}

\subsubsection{American National Standards Institute (ANSI)}

ANSUANS 6.1.1-1977

ANSI/ANS 6.1.1-1991

ANSI/ANS 6.4-1985
Neutron and Gamma-Ray Fluence-to-Dose Factors, 3/17/77

Neutron and Gamma-Ray Fluence-to-Dose Factors, 8/26/91

Guidelines on the Nuclear Analysis and Design of Concrete Radiation Shielding for Nuclear Power Plants, 3/1/85

\subsubsection{Code of Federal Regulations (CFR)}

10CFR20

Standards for Protection Against Radiation, Revised as of January 1, 1996

\subsubsection{NRC Regulatory Guides (RG)}

RG 8.8

Information Relevant to Ensuring That Occupational Radiation Exposures at Nuclear Power Stations Will be As Low As is Reasonably Achievable (ALARA), Revision 3, June 1978 (Second Proposed Revision 4, Draft OP 618-4, May 1982)

RG 8.10

Operating Philosophy for Maintaining Occupational Exposure ALARA, Revision 1-R, September 1975

\section{METHODOLOGY}

\subsection{GENERAL}

The approach to radiological design work is based upon the logical use of first principles in a systematic manner in order to obtain reasonable results. Radiation shielding design work is similarly structured such that a logical progression is made from simple models and calculations to more complicated models and sophisticated calculations. Shielding calculations are often initiated with simple hand calculations or simple computer codes in order to scope a shielding problem. In this manner, the problem may be bounded and thereby form the basis to progress to more complex models or calculations as warranted. Subsequent to any such calculation, a careful review by qualified personnel should be performed in order to determine the accuracy as well as adequacy of the information. Finally, ALARA evaluations will be required during the design process (Criteria 4.2.2) in order to obtain an optimal balance between shielding design and personnel protection.

Although shielding calculations may typically contain several conservative assumptions, the results of such calculations should not be relied upon without subsequent confirmation for personnel safety. In typical applications, radiological surveys are performed for confirmation 
of results in order to ensure such safety. If radiation conditions in excess of calculations are determined from surveys, subsequent evaluation and re-analysis may then be performed in order to determine the source of such discrepancies and to evaluate other potential problems. Additionally, administrative controls may be imposed as needed in order to ensure personnel safety.

\subsection{COMPUTER CODES}

A variety of calculational methods and computer codes may be used for radiation -shielding analyses. In many cases, more than one is required in order to provide assurance that results are either reasonable or bounded. Whenever differences are noted between calculations, such differences must be documented and understood before proceeding. All shielding calculations must identify the assumptions used to model the geometry, the source characteristics, and comparison analysis. The documentation should reflect the definitive design detail available at the time the calculation is made. As design features change or become better defined, the calculations are updated to ensure conformance with the criteria or regulations.

Radiation shielding computer codes used for quality affecting work are validated in accordance with Reference 7.2. This provides assurance that the software is used for its intended purpose, that the results are correct for the input provided, and that there is traceability for the products that result from the analysis.

Codes qualified in this regard include the following:

- $\quad \underline{M C N P 4 A}$

References $7.11,7.12$

MCNP4A is a highly versatile shielding and criticality code which is able to perform both gamma as well as neutron shielding calculations. Both continuous-energy cross section data as well as multi-group approximations to cross-section data may be used in calculations. A Monte Carlo technique is used in the code to statistically sample a large number of particle histories through a simulated geometry. The code is best suited for simulating a complex geometry of arbitrary three dimensional configurations of materials using first and second degree surfaces. Both coherent and incoherent photon scattering is simulated both with and without electron binding effects as well as florescent emission following photoelectric absorption. Extensive use of various statistical tallies and biasing methods are available but are highly demanding upon the user for an advanced physics and mathematical training as well as an appreciation of the correct application and interpretation of results.

Because of its versatility and capabilities, MCNP4A is the principal code for repository shielding design and analysis. This code will be used to evaluate the shielding configurations of the waste package and transporter, the in-drift concrete shadow shields, and personnel access in the main drift and turnout areas.

- MICROSHIELD

Reference 7.13

The code uses the point-kernel method for the solution of gamma shielding 
calculations involving relatively simple geometries. The code contains a highly useful graphical display system for the generation of two dimensional pictures of models as well as output in a number of different graphical displays. As with any point-kernel code, shielding calculations are limited in use for deep shielding types of geometries [more than 5 mean free paths] and for problems where scattered radiation may be an issue.

MICROSHIELD is useful for relatively simple geometry and conceptual analysis where scattered radiation effects or where deep penetration may be neglected. Preliminary and final design will likely require the use of more sophisticated codes such as MCNP4A, QAD-CGGP, and PATH.

QAD-CGGP (single source) $\quad$ Reference 7.14

The point-kernel line-of-sight QAD-CGGP code is used in cases where the configurations require a nonstandard setup. An example is the evaluation of penetrations and embedments upon the dose rate where scattering is not important. As with any point-kernel code, shielding calculations are limited in use for deep shielding types of geometries [more than 5 mean free paths] and for problems where scattered radiation may be an issue.

A stand-alone version of QAD-CGGP has been qualified for quality affecting work. QAD-CGGP is also part of the SCALE 4.3; consequently qualification of SCALE 4.3 will make QAD-CGGP available from this code group.

SCALE 4.3

References $7.8,7.15,7.16$

SCALE 4.3 consists of a suite of computer codes which includes adaptations of the KENO, ORIGEN, MORSE, QAD-CGGP, as well as a number of support codes for the calculation of problem specific multi group cross-sections, for heat transfer, and for graphical displays. The code was developed specifically to analyze shielding, criticality, and heat transfer problems associated with radioactive materials shipping casks. As with the MCNP code, extensive use of is made of various statistical tallies and biasing methods and are also highly demanding upon the user for advanced physics and mathematical training as well as an appreciation of the correct application and interpretation of results.

SCALE 4.3 is also useful for the generation of radiation source terms for repository shielding design and for quick check of other calculations. The 1-D and 3-D shielding modules of this code package may be used to verify calculations performed by other computer codes such as MCNP4A.

- $\quad$ PATH

References $7.17,7.18$

The PATH shielding code is a highly flexible shielding code which uses the pointkernel integration technique for analyzing gamma radiation shielding. The major features include complex geometry modeling capabilities, multiple source options, and an extensive nuclear data library. The code is best suited for the following scoping applications: gamma dose rate calculations, determination of gamma shield 
requirements from any radioactive components. As with any point-kernel code, the accuracy may be limited for deep penetration shielding geometries and to those applications where scattered radiation component is not important.

\subsection{ALARA}

The YMP ALARA program, Reference 7.19, refers to a design and operating philosophy which stands for "As Low As Reasonably Achievable," in regard to keeping occupational radiation exposure not only below legal limits but as low as can reasonably be reached. The program is embodied in Reference 7.19 and is designed to meet the requirements of 10CFR1101, Radiation Protection Programs, which requires any licensee to “.. use, to the extent practicable, procedures, and engineering controls based on sound radiation protection principles to achieve occupational doses and doses to members of the public that are as low as reasonably achievable (ALARA)."

This Design Guide recommends the use of the ALARA program of Reference 7.19 at the earliest stages of the design process. It is through the use of ALARA early on that meaningful results may be achieved in the most cost effective manner.

\subsection{PERSONNEL QUALIFICATIONS}

Radiological design entails a number of complex issues and technologies. Ultimately, such designs may impact on the safety and welfare of workers and the public. Consequently, personnel involved with either design or checking should be highly qualified to perform such work. In the case of radiological shielding, personnel should as a minimum have graduate level college course work in radiation shielding or equivalent experience. Additionally, personnel should be qualified in the application of sophisticated shielding codes such as MCNP4A or SCALE 4.3 through the participation in training courses specifically designed for such use. [The latter are available through LANL and ORNL respectively.]

\section{PERFORMANCE VERIFICATION}

Verification is required for many design calculations in order to assure that the design meets the intended goals and criteria. This is especially appropriate for those design calculations where health and safety issues are involved. In the case of shielding design, the associated calculations are generally the product of many assumptions and modeling decisions which are at best, approximations to actual conditions. Consequently, shielding calculations are predictions, which in turn require comparisons with actual results in order to provide the appropriate level of safety confirmation.

Verification of shielding results may be accomplished by comparing calculated results with field data that is obtained under controlled conditions. Such controls may include confirmation testing using pseudo radiation sources or by the use of graduated approaches to final radiation conditions. The advantage of confirmation tests is that they enable comparisons between calculations and actual data before designed facilities are fully and irrevocably committed.

Such testing will likely be performed which will provide the opportunity to determine those 
sources of design weakness. Refined shielding calculations will likely be required under such circumstances to determine the sources of error and to upgrade designs if required.

\section{REFERENCES}

7.1 Quality Assurance Requirements and Description, DOE/RW-0333P, Rev. 7.

7.2 Computer Software Qualification, Rev. 02, QAP-SI-0

7.3 Controlled Design Assumptions Document, B00000000-01717-4600-00032, Rev. 04, ICN 2.

7.4 Repository Design Requirements Document, YMP/CM-0023, Rev. 0, ICN 1.

7.5 Engineered Barrier Design Requirements Document, YMP/CM-0024, Rev. 0, ICN-1

7.6 LWR Radiological PC Database, CSCI:A00000000-02268-1200-20002 V1.1,9/13/93.

7.7 RSIC Computer Code Collection, ORIGEN2 - Isotope Generation and Depletion Code, Matrix Exponential Method, Oak Ridge National Laboratory, CCC-317, September 1989.

7.8 RSIC Computer Code Collection, SCALE 4.3: A Modular Code System for Performing Standardized Computer Analysis for Licensing Evaluation, Oak Ridge National Laboratory, CCC-545, October 1995.

7.9 Source Terms for Design Basis Event Analysis, DI: BBA000000-10717-0200-00019, Rev. 00 .

7.10 Neutron and Gamma-Ray Flux-to-Dose-Rate Factors, ANSI/ANS-6.1.1-1977, March 17, 1977.

7.11 RSIC Computer Code Collection, MCNP 4A-Monte Carlo N-Particle Transport Code System, CCC-200, Oak Ridge National Laboratory, January 1995.

7.12 MCNP4A QAP-SI-1 Baseline Submission Package for QA (SCM) Approval, CSCI: 30006 V4A, DI:30006-2001, -2002, -2003, and -2004, Rev. 01.

7.13 Software Qualification Report(SQR)for MicroShield V4.2, C.S.C.I.:30009 V4.2, DI:300102003 Rev. 00, MI:30009-M04-001

7.14 Software Qualification Report(SQR)for QAD-VCGGP-A, C.S.I.:30010 VCGGP-A, DI:30010-2003 Rev. 00, MI:30010-M04-001

7.15 Software Qualification Report for The SCALE Modular Code System (CSCI: 30004 V1.0), DI: 30004-2000 Rev 00.

7.16 Software Qualification Report for the SCALE Modular Code System Version 4.3, CSCI:30011 V4.3, DI: 30011-2002, Rev 00. 
7.17 S. Su et al, PATH Gamma Shielding Code User's Manual, GA-A16772 (Rev. 1), May 1987

7.18 Software Qualification Report for PATH/V88A - A Gamma Shielding Analysis Code, DI: 30007-2003 Rev 00.

7.19 Mined Geologic Disposal System ALARA Design Program, B00000000-01717-5705-00023, Rev. 00

7.20 GA-4 Legal Weight Truck From-Reactor Spent Fuel Shipping Cask Final Design Report, General Atomics, Document No. 910353/0, December 1993.

7.21 Material Compositions and Number Densities for Neutronics Calculations, BBA00000001717-0200-00002, Rev. 00.

7.22 Guidelines on the Nuclear Analysis and Design of Concrete Radiation Shielding for Nuclear Power Plants, ANSI/ANS-6.4-1985, March 1, 1985.

7.23 Accident Analysis for Nonmechanistic Waste Package Failure (Subsurface), BCA00000001717-0200-00001, Rev 00.

7.24 Mined Geologic Disposal System Advanced Conceptual Design Report,Vol.I to Vol V, B00000000-01717-5705-00027,Rev 00, March 1996.

7.25 Q-List, U.S. Department of Energy, YMP/90-55Q, Rev.04.

\section{LIST OF ACRONYMS AND ABBREVIATIONS}

$\begin{array}{ll}\text { ACD } & \text { Advanced Conceptual Design } \\ \text { ALARA } & \text { As Low As Reasonably Achievable } \\ \text { ANS } & \text { American Nuclear Society } \\ \text { ANSI } & \text { American National Standards Institute } \\ \text { B-poly } & \text { Borated polyethylene } \\ \text { B\&W } & \text { Babcock \& Wilcox } \\ \text { BWR } & \text { Boiling Water Reactor } \\ \text { cc } & \text { cubic centimeter } \\ \text { CDA } & \text { Controlled Design Assumptions } \\ \text { CDB } & \text { Characteristics Data Base } \\ \text { CFR } & \text { Code of Federal Regulations } \\ \text { Ci } & \text { Curies } \\ \text { CSCI } & \text { Computer Software Configuration Item } \\ \text { DBF } & \text { Design Basis Fuel } \\ \text { DCSS } & \text { Design Concept Subsurface } \\ \text { EBDRD } & \text { Engineered Barrier Design Requirements Document } \\ \text { EBS } & \text { Engineered Barrier Segment } \\ \text { FA } & \text { Fuel Assembly } \\ \text { FSD or fsd } & \text { Fractional Standard Deviation } \\ \text { GA } & \text { General Atomics } \\ \text { GROA } & \text { Geologic Repository Operations Area } \\ \text { LEF } & \text { Lower End Fittings } \\ \text { LANL } & \text { Los Alamos National Lab } \\ & \end{array}$




$\begin{array}{ll}\text { MeV } & \text { Millions of electron Volts } \\ \text { MGDS } & \text { Mined Geologic Disposal System } \\ \text { MTIHM } & \text { Metric Tons of Initial Heavy Metal } \\ \text { MTU } & \text { Metric Tons of Uranium (same as MTIHM) } \\ \text { MWD } & \text { Megawatt Days } \\ \text { n/s } & \text { Neutrons per second } \\ \text { NRC } & \text { Nuclear Regulatory Commission } \\ \text { ORNL } & \text { Oak Ridge National Laboratory } \\ \text { PC } & \text { Personal Computer } \\ \text { PWR } & \text { Pressurized Water Reactor } \\ \text { QARD } & \text { Quality Assurance Requirements Document } \\ \text { RDRD } & \text { Repository Design Requirements Document } \\ \text { RG } & \text { Regulatory Guide } \\ \text { SFD } & \text { Spent Fuel Disassembly } \\ \text { SNF } & \text { Spent Nuclear Fuel } \\ \text { STP } & \text { South Texas Project } \\ \text { TBD } & \text { To Be Determined } \\ \text { TBV } & \text { To Be Verified } \\ \text { TEDE } & \text { Total Effective Dose Equivalent } \\ \text { TN } & \text { Transnuclear } \\ \text { UEF } & \text { Upper End Fittings } \\ & \end{array}$




\section{ATTACHMENTS}

ATTACHMENT

I

II

III

IV
DESCRIPTION

DESIGN BASIS FUEL

AVERAGE PWR SPENT FUEL SOURCE TERMS TLME-DEPENDENT GAMMA SOURCE DATA MATERIAL DATA FOR SHIELDING ANALYSIS 


\section{DESIGN BASIS FUEL}

\section{PWR ACD DBF Neutron Source Data}

For PWR spent nuclear fuel, the neutron source strength is taken directly from the CDB. Since the neutron source spectrum is unavailable in the $C D B$, the neutron spectral data provided in the GA-4 spent fuel transportation cask design (Ref. 7.20) is used for this design analysis. The neutron source data for PWR ACD DBF are presented below:

Neutron Source Strength

$6.740 \mathrm{E}+8 \mathrm{n} / \mathrm{s}$ per MTIHM (part of computer output from Ref. 7.6)

Neutron Source Spectrum

\begin{tabular}{lll}
$\begin{array}{l}\text { Neutron Energy } \\
\text { Range }(\mathrm{MeV})\end{array}$ & $\begin{array}{c}\text { Unnormalized } \\
\text { Spectrum }^{\mathrm{a}}\end{array}$ & $\begin{array}{c}\text { Normalized } \\
\text { Spectrum }^{\mathrm{b}}\end{array}$ \\
\hline $6.43-20.0$ & $2.354 \mathrm{E}+05^{\mathrm{c}}$ & 0.0183 \\
$3.00-6.43$ & $2.691 \mathrm{E}+06$ & 0.2099 \\
$1.85-3.00$ & $3.002 \mathrm{E}+06$ & 0.2341 \\
$1.40-1.85$ & $1.680 \mathrm{E}+06$ & 0.1310 \\
$0.90-1.40$ & $2.265 \mathrm{E}+06$ & 0.1767 \\
$0.40-0.90$ & $2.466 \mathrm{E}+06$ & 0.1924 \\
$0.10-0.40$ & $4.827 \mathrm{E}+05$ & 0.0376 \\
$0.00-0.10$ & 0.0 & 0.0 \\
Total & $1.282 \mathrm{E}+07$ & 1.0
\end{tabular}

${ }^{a}$ Unnormalized spectrum from Ref. 7.6, p. 5.2-6 for $35,000 \mathrm{MWd} / \mathrm{MTIHM}$ burnup and $10 \mathrm{yr}$ decay. At $10 \mathrm{yr}$ decay, the neutron spectrum is insensitive to the burnup.

${ }^{6}$ Normalized to 1.0 (total) for input to the MCNP4A code. Example: The normalized spectrum for the 6.43 to $20.0 \mathrm{MeV}$ group $=(2.354 \mathrm{E}+05) /(1.282 \mathrm{E}+07)=0.0 .183$

${ }^{\mathrm{c}}$ Read as $2.354 \times 10^{5}$.

These parameters are used to obtain the ACD DBF neutron source term per waste package.

\section{PWR ACD DBF Gamma Source Data}

The gamma source strength for the active fuel regions of PWR ACD DBF is obtained from the $\mathrm{CDB}$. The $\mathrm{CDB}$ also provides the gamma source energy spectrum required for this design analysis as shown below: 
PWR ACD DBF Gamma Source Data (part of computer output from Ref. 7.6)

LWR Radiological DATABASE

PHOTONS REPORT

REACTOR TYPE \& BURNUP: PWR 48086

ENRICHMENT: $\quad 4.20 \%$

DECAY TIME: 10 YEARS

The data is shown in Photons per second/MTIHM

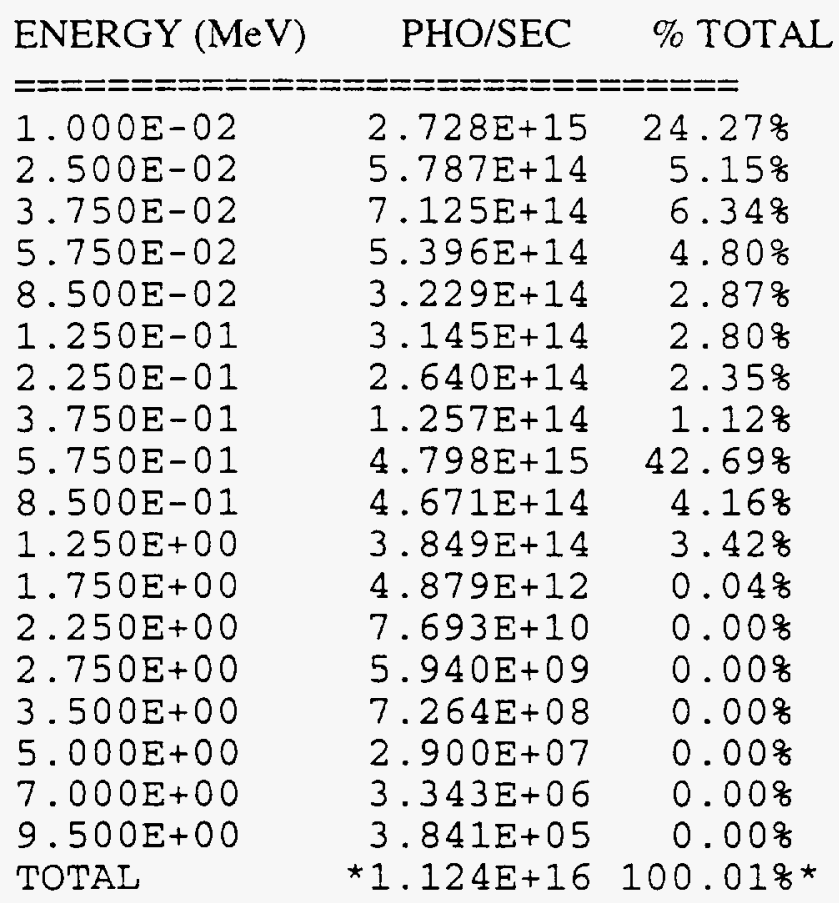

*This value was obtained by interpolating TOTALS values from ORIGEN2 runs to the specific burnup/enrichment/age combination you specified. Percentages have been calculated from this interpolated value and may not add up to 100 percent in all cases. (This paragraph is part of the computer output from Ref. 7.6).

These parameters are used to obtain the ACD DBF gamma source term per waste package. 


\section{AVERAGE PWR SPENT FUEL SOURCE TERMS}

The average spent fuel source data are used in this analysis for ALARA dose assessment. Consistent with the assumption in Section 4.3.1.1, the following source data are obtained from the CDB for average PWR spent fuel (assumed to be 26 years old with $39750 \mathrm{MWd} / \mathrm{MTIHM}$ burnup and $3.72 \mathrm{wt}$. \% enrichment):

Neutron Source Data

$2.241 \mathrm{E}+08 \mathrm{n} / \mathrm{s}$ per MTU (Ref. 7.6, computer output)

\section{Gamma Source Data}

Reproduced on next page from Ref. 7.6, computer output.

These parameters are used for ALARA evaluations. 
LWR Radiological DATABASE

PHOTONS REPORT

REACTOR TYPE \& BURNUP: PWR 39750

ENRICHMENT: $3.72 \%$

DECAY TIME: 26 YEARS

The data is shown in Photons per second/MTIHM

$\begin{array}{lcr}\text { ENERGY }(\mathrm{MeV}) & \text { PHO/SEC } & \text { \% TOTAL } \\ ========================= \\ 1.000 \mathrm{E}-02 & 1.503 \mathrm{E}+15 & 27.16 \% \\ 2.500 \mathrm{E}-02 & 2.981 \mathrm{E}+14 & 5.39 \% \\ 3.750 \mathrm{E}-02 & 3.599 \mathrm{E}+14 & 6.50 \% \\ 5.750 \mathrm{E}-02 & 3.247 \mathrm{E}+14 & 5.878 \\ 8.500 \mathrm{E}-02 & 1.633 \mathrm{E}+14 & 2.958 \\ 1.250 \mathrm{E}-01 & 1.274 \mathrm{E}+14 & 2.30 \% \\ 2.250 \mathrm{E}-01 & 1.375 \mathrm{E}+14 & 2.48 \% \\ 3.750 \mathrm{E}-01 & 5.727 \mathrm{E}+13 & 1.038 \\ 5.750 \mathrm{E}-01 & 2.469 \mathrm{E}+15 & 44.618 \\ 8.500 \mathrm{E}-01 & 3.741 \mathrm{E}+13 & 0.688 \\ 1.250 \mathrm{E}+00 & 5.668 \mathrm{E}+13 & 1.028 \\ 1.750 \mathrm{E}+00 & 1.140 \mathrm{E}+12 & 0.028 \\ 2.250 \mathrm{E}+00 & 1.763 \mathrm{E}+08 & 0.008 \\ 2.750 \mathrm{E}+00 & 5.487 \mathrm{E}+08 & 0.008 \\ 3.500 \mathrm{E}+00 & 2.209 \mathrm{E}+07 & 0.008 \\ 5.000 \mathrm{E}+00 & 9.470 \mathrm{E}+06 & 0.008 \\ 7.000 \mathrm{E}+00 & 1.091 \mathrm{E}+06 & 0.008 \\ 9.500 \mathrm{E}+00 & 1.253 \mathrm{E}+05 & 0.008\end{array}$

TOTAL *5.535E+15 $100.018 *$

*This value was obtained by interpolating TOTALS values from ORIGEN2 runs to the specific burnup/enrichment/decay time combination you specified. Percentages have been calculated from this interpolated value and may not add up to 100 percent in all cases. (This paragraph is part of the computer output from (Ref. 7.5) 